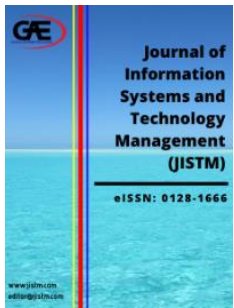

\author{
JOURNAL OF INFORMATION \\ SYSTEM AND TECHNOLOGY \\ MANAGEMENT (JISTM) \\ WWW.jistm.com
}

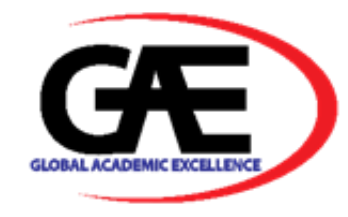

\title{
CHRONIC DISEASE MONITORING SYSTEM MODEL: STUDY ON EXISTING SYSTEM FEATURES AND TECHNOLOGIES
}

\author{
Akmal Afiq Abdul Haris ${ }^{1 *}$, Norshita Mat Nayan² \\ 1 Institute of IR4.0, National University of Malaysia, Malaysia \\ Email: akmalafiqharis@gmail.com \\ 2 Institute of IR4.0, National University of Malaysia, Malaysia \\ Email: norshitaivi@ukm.edu.my \\ * Corresponding Author
}

\section{Article Info:}

\section{Article history:}

Received date: 10.06 .2021

Revised date: 15.07 .2021

Accepted date: 20.08 .2021

Published date: 01.09.2021

\section{To cite this document:}

Haris, A. A. A., \& Mat Nayan, N. (2021). Chronic Disease Monitoring System Model: Study on Existing System Features and Technology. Journal of Information System and Technology Management, 6 (22), 103 114.

\section{DOI: $10.35631 / J I S T M .622009$}

This work is licensed under CC BY 4.0

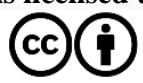

\begin{abstract}
:
The aim of this study is to review the currently available health monitoring systems to search for a gap in features and technologies that are available now. We performed a systematic literature review between January 2010 and March 2020 on few journal databases such as Elsevier ScienceDirect, IEEE Xplore, CORE, and Academia. A total of 1746 records were identified. In the selection process, we found 8 papers meeting the inclusion criteria. Data drawn from the 8 papers were synthesized in this study. All of the studies were on health monitoring systems that included their features and technologies and contained a model or prototype of a system and a list of diseases that the system supports. The results in this article show that all the health monitoring systems have similar use cases for each study but utilize different methodologies and technology. The Fourth Industrial Revolution capable devices such as IoT, smart devices, sensors,s and cloud computing are the most important pieces of technology for remote monitoring patients. We found that heart and lungrelated chronic diseases such as congestive heart failure (CHF) and chronic obstructive pulmonary disease (COPD) are the most in-focus chronic diseases that are currently using the health monitoring system. Based on the result, it can be seen that all of the studies on features of health monitoring systems are quite similar, with different approaches. The study was able to show us the advancement and variety of technologies used within the healthcare industry. Since this study focuses more on the features, technology, and disease listing, information on clinical trials is not included.
\end{abstract}

Keywords:

Health Monitoring System, Chronic Disease, Healthcare, Systematic Review 


\section{Introduction}

One of humanity's biggest concerns is health. With the decrease of human growth and increasing of chronic diseases in the population, humanity is at a threat of population collapse if left unmonitored and untreated. Chronic diseases are defined as conditions which last one year or more and which require ongoing medical treatment or restriction of daily activities (Bernell \& Howard, 2016). Few of the most common chronic diseases are heart disease, cancer, chronic respiratory disease, stroke, Alzheimer's, diabetes and chronic liver disease, which are by far the leading causes of death in the world (ASHG, 2019)(Ibhaze et al., 2016). Some of the most preventable chronic diseases share many risk factors, such as lack of physical exercise, poor nutrition, excessive body weight, smoking, and excessive alcohol consumption (Lin et al., 2018). The management of a chronic diseases involves the use of complex combinations of strategies to slow the progression of a chronic disease or to manage the high-risk factors associated with the chronic diseases (Lambrinou et al., 2019). Strategies aiming to help patients with chronic conditions improve their quality of life on a day-to-day basis. Both clinical and home-based strategies are used to manage care; individuals and families take part in their care (Waki et al., 2014). With the growing number of people with chronic diseases, the physiological parameters of the health of patients need to be tracked for early medical interventions to save their lives (Gómez et al., 2016)(Hong \& Lee, 2019).

Industrial Revolution 4.0 has shown the advancement of technology, as a result of which, there been an exponential growth in research on health monitoring systems. There is evidence that the current monitoring systems can help reduce the mortality rate and adverse events (Van Remoortel et al., 2012). A monitoring system is an organized component that observes and tracks certain actions by an application used on a computer or mobile device. This software is used for overseeing projects and generating data which is then delivered as a service (Jia et al., 2012). Health monitoring of patients is becoming important to optimize the use of available resources in modern technology. Vital signs are the physiological parameters used to demonstrate the health status of the patient including heart rate, blood pressure, and temperature. Metrics for a health care monitoring device may include body temperature, blood pressure, heart rate, and respiration rate (Quinn et al., 2014). With a mobile application, consumers do not need to use their device's web browser to retrieve their information. They also do not have to wait for websites to load. They can directly get their information in a quicker alternative way. It is in the framework that the data is kept (Jayatilleke et al., 2018).

The health industry was threatened in the year 2020, where the world was hit with a virus called Covid-19. The pandemic put chronic disease patients towards more unwanted risks. Traveling to the hospital could increase the risk of exposing the patient to Covid-19. Furthermore, the cost of staying in the hospital would be higher and more expensive than what is usually charged. The individual inpatient fee is costly (Esan et al., 2018). The healthcare professionals need to be present at all times to ensure patient safety and efficiency, which is difficult to achieve during a pandemic such as Covid-19. Other than that, the current health monitoring model is unable to motivate chronic disease patients to improve their overall health. In this study, we review the current available health monitoring systems to search for a gap in features and technologies that are available now.

\section{Methodology}

A systematic literature review was carried out according to the Preferred Reporting Items for Systematic Reviews and Meta Analyses (PRISMA) (Triantafyllidis et al., 2019), while following the guidelines of Kitchenham and Charters (Kitchenham et al., 2009)(Kitchenham 
Volume 6 Issue 22 (September 2021) PP. 103-114

DOI: 10.35631/JISTM.622009

\& Wohlin, 2005). An SLR provides a way to explore the data in-depth about a given problem. In order to explore the problems discussed in existing SLRs, we have focused on a few prominent questions in this study such as the features and technologies used.

\section{Key Questions}

This study had three key questions:

Table 1. Research Questions

\begin{tabular}{lll}
\hline ID & Research Question & Interest \\
\hline RQ1 & $\begin{array}{l}\text { What are the features } \\
\text { of the system? }\end{array}$ & $\begin{array}{l}\text { Identify the features for the } \\
\text { health monitoring system }\end{array}$ \\
RQ2 & $\begin{array}{l}\text { Which technology is } \\
\text { used in the study? }\end{array}$ & $\begin{array}{l}\text { Identify the technologies } \\
\text { required for the development } \\
\text { of the system }\end{array}$ \\
RQ3 & $\begin{array}{l}\text { What type of diseases is } \\
\text { the system being used to } \\
\text { monitor? }\end{array}$ & $\begin{array}{l}\text { Identify the type of diseases } \\
\text { system health monitoring }\end{array}$
\end{tabular}

\section{Inclusion and Exclusion Criteria}

Studies meeting the following criteria were included:

\section{Inclusion Criteria}

(a) Features: any health monitoring system with a valid or reasonable feature that is capable of getting or processing patient data.

(b) Technologies: using a known technology that has a working model or prototype.

(c) Method: method used in the development of the system.

(d) Diseases: any health monitoring system that is capable of monitoring general diseases will be accepted, but a health monitoring system built for chronic diseases will be prioritized.

(e) Study design: studies that evaluated the validity of the model, framework or working prototypes of health monitoring system.

(f) A search window between 1st of January 2010 until 1st of March 2020 was selected in order to capture health monitors in contemporary use.

\section{Exclusion Criteria}

(a) Studies like surveys.

(b) Duplicate studies like reviews.

(c) Studies published in languages other than English. 


\section{Search Process}

DOI: 10.35631/JISTM.622009

The search process was involved searching for specific journal papers related to health monitoring since 1st of January 2010. The selected databases used for journal sources are shown in Table 2. The journals were selected because they complied with the keywords used and they had all the information needed, such as features of the health monitoring system, technologies required for system development, methodology used during the development of the system, and type of diseases it used to monitor.

The search strings are based on simple keywords. The keywords used in the search are shown below.

- Health Monitor

- Health Monitoring System

- $\quad$ Health Monitoring System Chronic Diseases

- $\quad$ Health Monitoring System Features

- Health Monitoring System Technology

Table 2. Journal Sources Database

\begin{tabular}{lll}
\hline Source & Acronym & Link \\
\hline $\begin{array}{l}\text { Elsevier } \\
\text { ScienceDirect }\end{array}$ & SD & https://www.sciencedirect.com/ \\
IEEE Xplore & IEEE & https://ieeexplore.ieee.org/ \\
CORE & CORE & https://core.ac.uk/ \\
Academia & AC & https://www.academia.edu/ \\
\hline
\end{tabular}

\section{Result}

The systematic review identified 1746 papers in the surveyed databases. At first, 1667 papers were omitted because they did not have an association for the key questions in their keywords, title, and filtered by date. Then, 47 studies were excluded after reviewing the title and abstract. With the review of the full-text papers against the eligibility criteria, 24 studies were excluded, resulting in 8 papers which were included in this study (Fig. 1). 
Volume 6 Issue 22 (September 2021) PP. 103-114 DOI: 10.35631/JISTM.622009

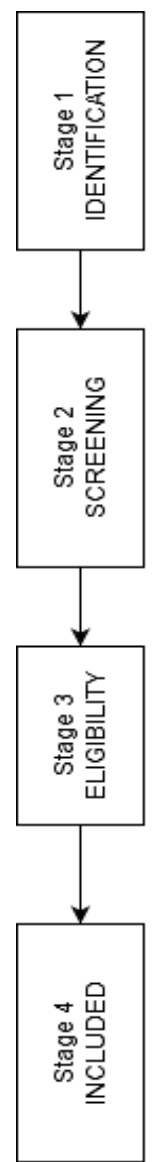

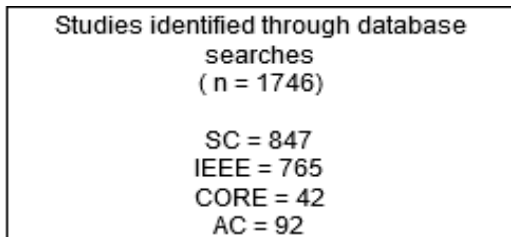

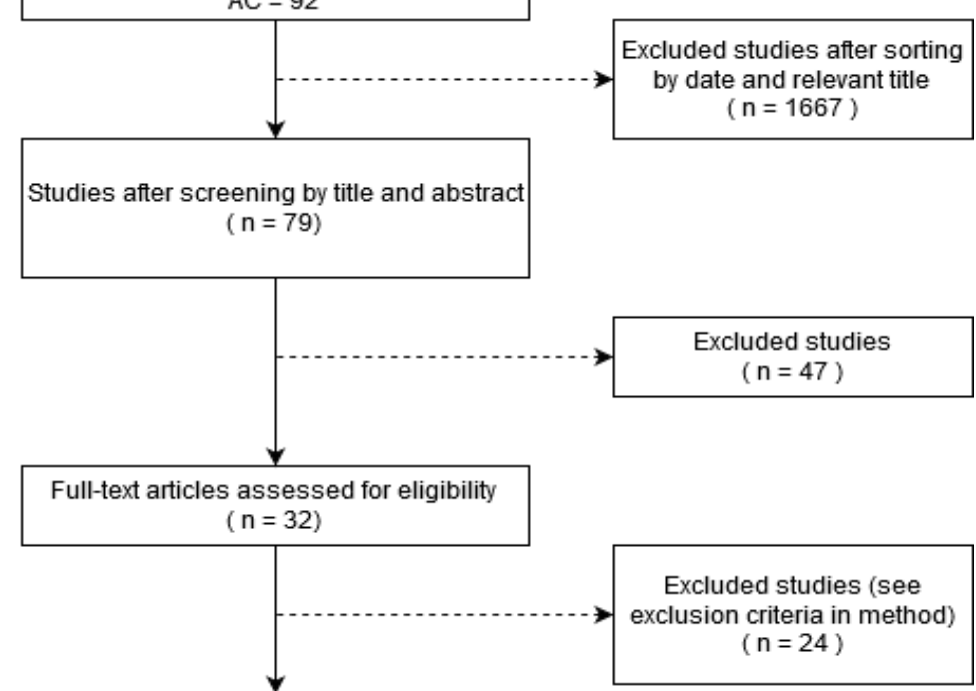

Studies included in the systematic review

$(\mathrm{n}=8)$

$\mathrm{SC}=2$

$\mathrm{IEEE}=1$

CORE $=4$

$\mathrm{AC}=1$

Figure 1: Search Process 
DOI: $10.35631 / J I S T M .622009$

Volume 6 Issue 22 (September 2021) PP. 103-114

Monitoring health systems are widely used in the healthcare industry with different features and evolving technologies (Lin et al., 2018). Table 3 is produced based on the search process using systematic literature review. All the data such as system features, technologies, and type of disease has been compiled into Table 3. It shows the existing health monitoring systems which contain the complete model for our research purpose. All the tabulated data will be analysed in next section of the paper, which is findings and discussion.

Table 3. Overview of Existing Health Monitoring Systems

\begin{tabular}{|c|c|c|c|c|c|}
\hline Author & Title & Features & Technology & Type of Disease & Summary \\
\hline $\begin{array}{l}\text { (Akinwol } \\
\text { e et al., } \\
\text { 2019) }\end{array}$ & $\begin{array}{l}\text { Using Mobile-Enabled } \\
\text { Devices for } \\
\text { Engagement and } \\
\text { Monitoring of Patient } \\
\text { with Chronic Disease: } \\
\text { Hypertensive Case }\end{array}$ & $\begin{array}{l}\text { Monitor patient Blood } \\
\text { Pressure }\end{array}$ & $\begin{array}{l}\text { Sensor, PC and } \\
\text { Server }\end{array}$ & Hypertension & $\begin{array}{l}\text { Remote Patient Monitoring } \\
\text { System for monitoring } \\
\text { patients with chronic } \\
\text { conditions like hypertension. }\end{array}$ \\
\hline $\begin{array}{l}\text { (Subasi et } \\
\text { al., 2020) }\end{array}$ & $\begin{array}{l}\text { Cloud-based health } \\
\text { monitoring framework } \\
\text { using smart sensors and } \\
\text { smartphone }\end{array}$ & $\begin{array}{l}\text { Risk assessment chronic } \\
\text { disorders such as CHF or } \\
\text { epileptic seizure }\end{array}$ & $\begin{array}{l}\text { Sensors, } \\
\text { Smartphone } \\
\text { and cloud } \\
\text { computing }\end{array}$ & Heart attack & $\begin{array}{l}\text { Employment of market-ready } \\
\text { devices for biomedical signal } \\
\text { monitoring in a cloud-based } \\
\text { mobile environment. }\end{array}$ \\
\hline $\begin{array}{l}\text { (Agapito } \\
\text { et al., } \\
\text { 2018) }\end{array}$ & $\begin{array}{l}\text { DIETOS: a dietary } \\
\text { recommender system } \\
\text { for chronic diseases } \\
\text { monitoring and } \\
\text { management }\end{array}$ & $\begin{array}{l}\text { Health profiling based on } \\
\text { user answers to dynamic } \\
\text { real-time medical } \\
\text { questionnaires }\end{array}$ & $\begin{array}{l}\text { Mobile and } \\
\text { web-based } \\
\text { applications }\end{array}$ & $\begin{array}{l}\text { Chronic Kidney } \\
\text { Disease (CKD) }\end{array}$ & $\begin{array}{l}\text { A recommender system for } \\
\text { the adaptive delivery of } \\
\text { nutrition contents to improve } \\
\text { the quality of life of both } \\
\text { healthy subjects and patients } \\
\text { with diet-related chronic } \\
\text { diseases. }\end{array}$ \\
\hline $\begin{array}{l}\text { (Basilaki } \\
\text { s et al., } \\
\text { 2010) }\end{array}$ & $\begin{array}{l}\text { Design of a Decision- } \\
\text { Support Architecture } \\
\text { for Management of } \\
\text { Remotely Monitored } \\
\text { Patients }\end{array}$ & $\begin{array}{l}\text { Provide a means of health } \\
\text { risk stratification to allow } \\
\text { appropriate targeting of } \\
\text { clinical resources to best } \\
\text { manage the health of the } \\
\text { patient }\end{array}$ & $\begin{array}{l}\text { Telehealth } \\
\text { monitor } \\
\text { system, Web } \\
\text { Application }\end{array}$ & $\begin{array}{l}\text { Congestive Heart } \\
\text { failure (CHF) and } \\
\text { Chronic Obstructive } \\
\text { Pulmonary Disease } \\
\text { (COPD) }\end{array}$ & $\begin{array}{l}\text { Telehealth with Decision } \\
\text { Support System. Framework } \\
\text { combined with rules engine } \\
\text { and statistical analysis tools. } \\
\text { Analyze data for trends and } \\
\text { shifts that exceed }\end{array}$ \\
\hline
\end{tabular}

Copyright $\odot$ GLOBAL ACADEMIC EXCELLENCE (M) SDN BHD - All rights reserved 
predetermined or adaptive thresholds.

(Ibhaze et E-health monitoring al., 2016) system

(Zanjal \& Medicine Reminder

Talmale, and Monitoring System

2016) for Secure Health using IOT

\section{(Venkata IOT Based Health Care}

Sateesh System

Yadav \&

Vishwant

h, 2018)

\section{(Ramalin Self-Monitoring}

gam et Framework for Patients

al., 2019) in IOT based

Healthcare System
Monitor patients' vital parameters, no matter where they are located

Remember prescription, remote observing and update new drug information of patients, which should be possible by prescriber through web

Monitor body temperature, pulse rate, and kidney functioning

\section{Monitor patient pulse and} temperature

Smart TV and
Sensor, Mobile Diabetic

Phone, and

IOT

Web Services, Heart Disease

Mobile Phone

IOT and

Mobile Phone

General Health

Sensor, Mobile General Health Phone, and

IOT
E health system that allows doctors to closely monitor patients' vital parameters. Remember prescription, remote observing and update new drug information of patients, which should be possible by prescriber through web.

IOT based architecture for health-related issues such as diabetics, heart monitoring system, body temperature, pulse rate, and kidney function

Design a monitoring system using a sensor and microcontroller to be used by the patients at their home.

Congestive heart failure (CHF), Internet of Things (IOT), Chronic Kidney Disease (CKD), Chronic Obstructive Pulmonary Disease (COPD) 


\section{Findings and Discussion}

\section{Features used in Health Monitoring Systems}

Since these studies are for Health Monitoring Systems, therefore most of the features relate to patient monitoring and management. Table 4 shows the features data that has been extracted from the literature in Table 3. As for the use cases for each study, they are rather similar with different methodology and technology. There are a few studies that stood out the most in term of features, which are Diet Management, Medicine Reminder, and Risk assessment. This shows that the patient data representing big data is the fuel for the Fourth Industrial Revolution. Research from Akinwole et al. (2019), Subasi et al. (2020), Zanjal \& Talmale (2016), and Ramalingam et al. (2019) focused more on monitoring the data that has been received from the sensors. While other systems are based on the user input and output based on the patient condition.

Table 4. Existing Features on Health Monitoring System

\begin{tabular}{|c|c|}
\hline Author & Features \\
\hline $\begin{array}{l}\text { (Akinwole et al., } \\
\text { 2019) }\end{array}$ & Monitor patient Blood Pressure \\
\hline (Subasi et al., 2020) & $\begin{array}{l}\text { Risk assessment chronic disorders } \\
\text { such as CHF or epileptic seizure }\end{array}$ \\
\hline (Agapito et al., 2018) & $\begin{array}{l}\text { Health profiling based on user answers } \\
\text { to dynamic real-time medical } \\
\text { questionnaires }\end{array}$ \\
\hline $\begin{array}{l}\text { (Basilakis et al., } \\
\text { 2010) }\end{array}$ & $\begin{array}{l}\text { Provide a means of health risk } \\
\text { stratification to allow appropriate } \\
\text { targeting of clinical resources to best } \\
\text { manage the health of the patient }\end{array}$ \\
\hline (Ibhaze et al., 2016) & $\begin{array}{l}\text { Monitor patients' vital parameters, no } \\
\text { matter where they are located }\end{array}$ \\
\hline $\begin{array}{c}\text { (Zanjal \& Talmale, } \\
\text { 2016) }\end{array}$ & $\begin{array}{l}\text { Remember prescription, remote } \\
\text { observing and update new drug } \\
\text { information of patients, which should } \\
\text { be possible by prescriber through web }\end{array}$ \\
\hline $\begin{array}{l}\text { (Venkata Sateesh } \\
\text { Yadav \& Vishwanth, } \\
\text { 2018) }\end{array}$ & $\begin{array}{l}\text { Monitor body temperature, pulse rate } \\
\text { and kidney functioning }\end{array}$ \\
\hline $\begin{array}{l}\text { (Ramalingam et al., } \\
\text { 2019) }\end{array}$ & Monitor patient pulse and temperature \\
\hline
\end{tabular}

\section{Technologies used in Health Monitoring Systems}

Smart devices, IoT, smart sensors, and cloud computing are the most important pieces of technology within the Fourth Industrial Revolution used for remote monitoring patients. Table 5 shows the technologies data that has been extracted from the literature in Table 3. Smart devices have been more potent with the emersion of cloud computing which enables long distance patients to communicate with their doctors. Patients benefit greatly with this technology since long distance monitoring can effectively reduce time and cost for the patient (Basilakis et al., 2010)(Mohammadzadeh \& Safdari, 2014). IoT and sensors have amplified the medical technology in terms of complexity and advanced tech while remaining cheap to 
Volume 6 Issue 22 (September 2021) PP. 103-114

DOI: 10.35631/JISTM.622009

produce in large quantities, thereby benefiting the consumer (Subasi et al., 2020)(Chiauzzi et al., 2015). All of the Authors used similar technologies with different features and methodological approaches.

Table 5. Existing Technologies on Health Monitoring System

\begin{tabular}{|c|c|}
\hline Author & Technology \\
\hline (Akinwole et al., 2019) & Sensor, PC and Server \\
\hline (Subasi et al., 2020) & $\begin{array}{l}\text { Sensors, Smartphone and cloud } \\
\text { computing }\end{array}$ \\
\hline (Agapito et al., 2018) & Mobile and web-based applications \\
\hline (Basilakis et al., 2010) & $\begin{array}{l}\text { Telehealth monitor system, Web } \\
\text { Application }\end{array}$ \\
\hline (Ibhaze et al., 2016) & $\begin{array}{l}\text { Web Services, Smart TV and } \\
\text { Mobile Phone }\end{array}$ \\
\hline (Zanjal \& Talmale, 2016) & IOT and Mobile Phone \\
\hline $\begin{array}{c}\text { (Venkata Sateesh Yadav \& } \\
\text { Vishwanth, 2018) }\end{array}$ & Sensor, Mobile Phone, and IOT \\
\hline (Ramalingam et al., 2019) & Sensor, Mobile Phone, and IOT \\
\hline
\end{tabular}

Types of Diseases supported by Health Monitoring System

Some of the studies focused on a certain type of disease and some focused on the individual health. We found that heart and lung related chronic diseases such as congestive heart failure (CHF) and chronic obstructive pulmonary disease (COPD) are the most in-focus chronic diseases that are using health monitoring systems. Table 5 shows the list of diseases that the health monitoring system was used for. While some of the researches focus on a specific disease, the methodology can be tweaked to change the features to support other diseases, since they all use similar technology.

Table 6. Type Of Disease on Existing Health Monitoring System

\begin{tabular}{ll}
\hline Author & Type of Disease \\
\hline (Akinwole et al., 2019) & Hypertension \\
(Aguasi et al., 2020) & Heart attack \\
(Basilakis et al., 2010) & $\begin{array}{l}\text { Chronic Kidney } \\
\text { Disease (CKD) }\end{array}$ \\
& $\begin{array}{l}\text { Cailure (CHF) and } \\
\text { Chronic Obstructive } \\
\text { Pulmonary Disease } \\
\text { (COPD) }\end{array}$ \\
(Ibhaze et al., 2016) & Heart Disease \\
(Zanjal \& Talmale, 2016) & General Health \\
(Venkata Sateesh Yadav & Diabetic \\
\& Vishwanth, 2018) & \\
(Ramalingam et al., 2019) & General Health \\
\hline
\end{tabular}




\section{Conclusion}

In this paper, we show the purpose of the study using a systematic literature review to find and understand the features and technology for health monitoring systems, by conducting a search on the previously published research between 2010 and 2020 on several popular database journals. All of the studies on features of health monitoring systems are quite similar, with different approaches. The study was able to show us the advancement and variety of technologies used within the Fourth Industrial Revolution for the healthcare industry. We found that all of the health monitoring systems had similar features, while some had added an extra feature such as Diet Management, Medicine Reminder, and Risk assessment. Within the discussion, it is shown that smart devices working in conjunction with sensors, internet of things, and the cloud computing is the most common working model. Most of the studies are able to provide proof of their methodology, which consists of a model or prototype and the diseases it is used for. With our findings, we will develop our own health monitoring model based on informatic intervention. Since this study focuses more on the features, technology and diseases listing, information on clinical trials is not included.

\section{Acknowledgement}

This study was funded by a University Research Grant (TAP-K020093), Universiti Kebangsaan Malaysia

\section{References}

Agapito, G., Simeoni, M., Calabrese, B., Caré, I., Lamprinoudi, T., Guzzi, P. H., Pujia, A., Fuiano, G., \& Cannataro, M. (2018). DIETOS: A dietary recommender system for chronic diseases monitoring and management. Computer Methods and Programs in Biomedicine, 153, 93-104. https://doi.org/10.1016/j.cmpb.2017.10.014

Akinwole, A. K., Yekini, N. A., Oloyede, A. O., \& Ojo, O. (2019). Using Mobile-Enabled Devices for Engagement and Monitoring of Patient with Chronic Disease: Hypertensive Case. 10(4), 1314-1322.

ASHG. (2019). A Report of the Aspen Health Strategy Group A Report of the Aspen Health Strategy Group.

Basilakis, J., Lovell, N. H., Redmond, S. J., \& Celler, B. G. (2010). Design of a decisionsupport architecture for management of remotely monitored patients. IEEE Transactions on Information Technology in Biomedicine, 14(5), 1216-1226. https://doi.org/10.1109/TITB.2010.2055881

Bernell, S., \& Howard, S. W. (2016). Use Your Words Carefully: What Is a Chronic Disease? Frontiers in Public Health, 4(August), 2-4. https://doi.org/10.3389/fpubh.2016.00159

Chiauzzi, E., Rodarte, C., \& DasMahapatra, P. (2015). Patient-centered activity monitoring in the self-management of chronic health conditions. BMC Medicine, 13(1), 1-6. https://doi.org/10.1186/s12916-015-0319-2

Esan, A., Olaniyan, O., Adeyanju, I., \& Analytics, D. (2018). Wireless Sensor Network Based Health Monitoring System for Hypertensive In-Patients. 3(September), 102-107.

Gómez, J., Oviedo, B., \& Zhuma, E. (2016). Patient Monitoring System Based on Internet of Things. Procedia Computer Science, 83(Ant), 90-97. https://doi.org/10.1016/j.procs.2016.04.103

Hong, Y., \& Lee, S. H. (2019). Effectiveness of tele-monitoring by patient severity and intervention type in chronic obstructive pulmonary disease patients: A systematic review and meta-analysis. International Journal of Nursing Studies, 92, 1-15. https://doi.org/10.1016/j.ijnurstu.2018.12.006 


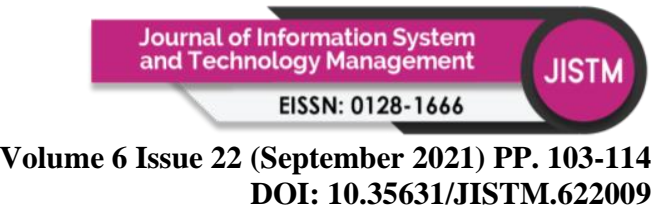

Ibhaze, A. E., Eleanor, E. C., \& Idachaba, F. E. (2016). E-health monitoring system for the aged. 2016 IEEE International Conference on Emerging Technologies and Innovative Business Practices for the Transformation of Societies, EmergiTech 2016, November, 298-299. https://doi.org/10.1109/EmergiTech.2016.7737355

Jayatilleke, B. G., Ranawaka, G. R., Wijesekera, C., \& Kumarasinha, M. C. B. (2018). Development of mobile application through design-based research. Asian Association of Open Universities Journal, 13(2), 145-168. https://doi.org/10.1108/aaouj-02-20180013

Jia, X., Chen, H., \& Qi, F. (2012). Technical models and key technologies of E-Health Monitoring. 2012 IEEE 14th International Conference on E-Health Networking, Applications and Services, Healthcom 2012, 23-26. https://doi.org/10.1109/HealthCom.2012.6380059

Kitchenham, B., Pearl Brereton, O., Budgen, D., Turner, M., Bailey, J., \& Linkman, S. (2009). Systematic literature reviews in software engineering - A systematic literature review. Information and Software Technology, 51(1), 7-15. https://doi.org/10.1016/j.infsof.2008.09.009

Kitchenham, B., \& Wohlin, C. (2005). Editorial: Systematic Reviews in Information and Software Engineering. Information and Software Technology, 2005-2008.

Lambrinou, E., Hansen, T. B., \& Beulens, J. W. J. (2019). Lifestyle factors, self-management and patient empowerment in diabetes care. European Journal of Preventive Cardiology, 26(2_suppl), 55-63. https://doi.org/10.1177/2047487319885455

Lin, R., Ye, Z., Wang, H., \& Wu, B. (2018). Chronic Diseases and Health Monitoring Big Data: A Survey. IEEE Reviews in Biomedical Engineering, 11(c), 275-288. https://doi.org/10.1109/RBME.2018.2829704

Mohammadzadeh, N., \& Safdari, R. (2014). Patient monitoring in mobile health: opportunities and challenges. Medicinski Arhiv, 68(1), 57-60. https://doi.org/10.5455/medarh.2014.68.57-60

Quinn, C. C., Sareh, P. L., Shardell, M. L., Terrin, M. L., Barr, E. A., \& Gruber-Baldini, A. L. (2014). Mobile diabetes intervention for glycemic control: Impact on physician prescribing. Journal of Diabetes Science and Technology, 8(2), 362-370. https://doi.org/10.1177/1932296813514503

Ramalingam, M., Puviarasi, R., Chinnavan, E., \& Foong, H. K. (2019). Self-monitoring framework for patients in IoT-based healthcare system. International Journal of Innovative Technology and Exploring Engineering, 8(12), 3641-3645. https://doi.org/10.35940/ijitee.L3813.1081219

Subasi, A., Bandic, L., \& Qaisar, S. M. (2020). Cloud-based health monitoring framework using smart sensors and smartphone. In Innovation in Health Informatics. Elsevier Inc. https://doi.org/10.1016/b978-0-12-819043-2.00009-5

Triantafyllidis, A., Kondylakis, H., Votis, K., Tzovaras, D., Maglaveras, N., \& Rahimi, K. (2019). Features, outcomes, and challenges in mobile health interventions for patients living with chronic diseases: A review of systematic reviews. International Journal of Medical Informatics, 132(June 2018), 103984. https://doi.org/10.1016/j.ijmedinf.2019.103984

Van Remoortel, H., Giavedoni, S., Raste, Y., Burtin, C., Louvaris, Z., Gimeno-Santos, E., Langer, D., Glendenning, A., Hopkinson, N. S., Vogiatzis, I., Peterson, B. T., Wilson, F., Mann, B., Rabinovich, R., Puhan, M. A., Troosters, T., Chiesi Farmaceutici, S. A., Brindicci, C., Higenbottam, T., ... Damijen Erzen. (2012). Validity of activity monitors in health and chronic disease: a systematic review. International Journal of Behavioral Nutrition and Physical Activity, 9. https://doi.org/10.1186/1479-5868-9-84

Copyright $\odot$ GLOBAL ACADEMIC EXCELLENCE (M) SDN BHD - All rights reserved 
Volume 6 Issue 22 (September 2021) PP. 103-114 DOI: 10.35631/JISTM.622009

Venkata Sateesh Yadav, K., \& Vishwanth, M. (2018). IoT based health care monitoring system. Journal of Advanced Research in Dynamical and Control Systems, 10(8), 213220. https://doi.org/10.22214/ijraset.2019.6171

Waki, K., Fujita, H., Uchimura, Y., Omae, K., Aramaki, E., Kato, S., Lee, H., Kobayashi, H., Kadowaki, T., \& Ohe, K. (2014). DialBetics: A novel smartphone-based selfmanagement support system for type 2 diabetes patients. Journal of Diabetes Science and Technology, 8(2), 209-215. https://doi.org/10.1177/1932296814526495

Zanjal, S. V., \& Talmale, G. R. (2016). Medicine Reminder and Monitoring System for Secure Health Using IOT. Physics Procedia, 78(August), 471-476. https://doi.org/10.1016/j.procs.2016.02.090 